\title{
Influence of environmental factors on the dynamics of macrobenthic crustaceans on soft-bottoms of the Ebro Delta continental shelf (northwestern Mediterranean)
}

\author{
SILVIA DE JUAN and JOAN E. CARTES \\ Instituto de Ciencias del Mar-CSIC, Paseo Marítimo de la Barceloneta 37-49, 08003, Barcelona, Spain. \\ E-mail: sdejuan@icm.csic.es
}

\begin{abstract}
SUMMARY: Short-term temporal variability in infaunal crustacean communities was evaluated against environmental variability. The area of study was located at two stations at 45 and $60 \mathrm{~m}$ depth under the influence of the Ebro River. Differences in the relative abundance of crustacean species between sites might be related to the distance from the river, with higher organic matter supply and finer mud content near the river. There was a marked seasonal variability linked to high phytoplankton production in spring, which supplied organic matter to the benthos, inducing higher crustacean abundance. In late summer there was a reduction in the infaunal crustacean abundance and species richness that could have been caused by two factors: the establishment of the thermocline, which could limit the availability of organic matter to the seabed, and the high water temperatures, which caused the production of phytoplankton exudates and accumulation of mucilaginous aggregates over the seabed. The $45-\mathrm{m}$ site was under the influence of otter-trawl fishing and precisely in this area the seasonal variability was not observed, probably masked by the effects of trawling impact.
\end{abstract}

Keywords: Peracarida, benthos, spatial variations, muddy sediments, temperature, mucilaginous aggregates.

\begin{abstract}
RESUMEN: INFLUENCIA DE FACTORES AMBIENTALES EN LA DINÁMICA DE CRUSTÁCEOS MACROBENTÓNICOS EN FONDOS fangosos de la plataforma continental del Delta del Ebro (Mediterráneo noroccidental). - Evaluamos la variabilidad temporal de la comunidad de crustáceos endobentónicos frente a la variabilidad ambiental a pequeña escala. El estudio se sitúa en la plataforma continental frente a la desembocadura del Rio Ebro, en dos estaciones de muestreo a 45 y 60 $\mathrm{m}$ de profundidad. Las diferencias en la abundancia relativa de crustáceos entre las dos estaciones pueden estar relacionadas con la distancia a la desembocadura del Ebro, con un mayor aporte de materia orgánica y mayor contenido de fango cerca del rio. Observamos una variabilidad estacional relacionada con la alta producción de fitoplancton en primavera, con aportes de materia orgánica al bentos favoreciendo una mayor abundancia de crustáceos. Al final del verano se establece la termoclina, pudiendo limitar el aporte de materia orgánica al bentos, y junto con las altas temperaturas, que originaron acumulaciones de exudados de fitoplancton en el fondo, pudo causar una reducción en la abundancia y riqueza específica. La variabilidad estacional no es tan marcada en la estación de muestreo a $45 \mathrm{~m}$. Esta zona está impactada por la pesca de arrastre, que probablemente enmascara la variabilidad temporal.
\end{abstract}

Palabras clave: Peracarida, bentos, variabilidad espacial, sedimento fangoso, temperatura, agregados mucilaginosos.

\section{INTRODUCTION}

Most studies on infaunal communities in the Mediterranean have focused on the accessible coastal areas. Consequently, there is a lack of knowledge on the temporal dynamics of benthic assemblages over soft-bottoms of continental shelves, and little is known about short-term changes in the composition of these assemblages (see Salen-Picard et al., 2003; Cartes et al., 2007; Hermand et al., 2008; Cartes et al., 2009). Though many studies on soft-bottom macrofauna carried out over decades have addressed a wide range of aspects, most of them focus on diversity patterns (e.g. Gray, 2000; Ellingsen and Gray, 2002; Hewitt et al., 
2005) and the species distribution over spatial and environmental gradients (e.g. Clarke and Ainsworth, 1993; Ellingsen, 2002; Gobin and Warwick, 2006). The relationship between production partitioning and trophic strategies (Warwick, 1982; Buchanan and Warwick, 1974) and responses to organic matter inputs (Pearson and Rosenberg, 1978; Gremare et al., 1997) are of great importance as macrobenthos plays an important role in ecosystem processes in soft-bottoms, including nutrient cycling, dispersion and burial, and secondary production (Snelgrove, 1998; Lohrer et al., 2004). In this context few studies have considered the seasonal variation of macrofaunal communities linked to a detailed analysis of environmental variables on continental shelves (Buhl-Jensen and Fosså, 1991; Richoux et al., 2004; Cartes et al., 2007). The main findings in the Mediterranean are related to changes in food input and in the production rates of species at short-term (Gremare et al., 1998) and small spatial (Cartes et al., 2009) scales.

Rivers are important carriers of land sediment and organic matter to the seas, so areas associated with rivers are highly productive and the effects of natural variability on communities inhabiting these environments are of great interest (Salen-Picard et al., 2003; Darnaude et al., 2004). These areas are also strongly affected by anthropogenic activities, including pollution from river runoff, high sedimentation from terrestrial erosion and fishing on the associated continental shelves (Drinkwater and Frank, 1994; Thrush et al., 2006; Oczkowski et al., 2009). The Ebro river, flowing in the northeast of the Iberian Peninsula, is one of the three most important rivers in terms of river flow in the Mediterranean (Palanques and Drake, 1990), with an annual cycle of high flows between November and May and low flows from June to September in 2002-2004 (Cartes et al., 2007). However, though it is a highly productive area supporting an important fishery activity (Demestre et al., 2008), the dynamics of benthos off the Ebro Delta are poorly known, and only recently have we obtained estimations on the secondary production of suprabenthic and infaunal crustaceans (Cartes et al., 2007, 2009). This deltaic system has a high discharge of mud and organic matter and we expect macrofauna to be essential for the trophic webs in the area.

Infaunal samples and physical data were simultaneously collected under the framework of a research project aimed at evaluating fishing impact on benthos off the Ebro Delta (RESPONSE, Q5RS-2002-00787; Demestre, 2006). These data are limited due to an incomplete annual cycle, but they include samples from early summer to autumn that are of high interest in the Mediterranean as this is a period of strong physical changes. Therefore, these data provided the opportunity of evaluating seasonal changes in the infaunal community structure and dynamics in relation to environmental variability on the continental shelf off the Ebro Delta.
In the area covered in this study, Cartes et al. (2009) found changes in the $P / B$ ratio of crustaceans (mainly peracarids) likely linked to differences in temperature and organic matter content (\% TOC). In a second study in the same area, Cartes et al., (2007) investigated temporal changes in suprabenthic crustaceans, which were linked to oscillations in the river discharge and the establishment of a thermocline. In the present paper we study the crustaceans from the infaunal community at two sites off the Ebro Delta in order to investigate the relationships between changes in the community assemblages and environmental variability. We expected the infaunal organisms to be less affected by the hydrography and highly dependent on the sediment type and the local availability of organic matter (Ellingsen, 2002; Darnaude et al., 2004; Hermand et al., 2008). Moreover, one of the study sites is impacted by the trawling fleet operating in the area and, whereas the suprabenthic community did not respond to this disturbance, we would expect the dynamics of the infaunal crustaceans to be conditioned by the trawling activities (as observed for the entire benthic community in de Juan et al., 2007a). We worked on crustaceans (mainly on peracarids) because, after polychaetes, crustaceans are the most dominant and diversified group in the infaunal communities, having a variety of ecological functions (e.g. trophic habits and production rates) depending on the environmental condition (Cartes et al., 2009). Furthermore, peracarids have no free larvae as embryonic development occurs in oostegal bags (marsupia) developed by reproductive females. Therefore, peracarids may be expected a priori to be especially vulnerable to disturbance induced by both environmental variability and human activity due to their lower recolonization rates (Dauvin and Gentil, 1990; Cartes et al., 2009).

\section{MATERIALS AND METHODS}

\section{Study area}

The study area was located at around $50 \mathrm{~m}$ depth in the northwestern Mediterranean on the continental shelf off the Ebro Delta (Fig. 1). This area is characterized by muddy sediments, with an average of $99 \%$ mud, an epibenthic community dominated by crustaceans and echinoderms, and a macroinfaunal community dominated by polychaetes, which represent up to $70 \%$ of the overall abundance (de Juan et al., 2007a). This area is under the influence of the Ebro River and is also a productive fishing ground (Demestre et al., 2008). Two sites were established within the study area: S1 was located at $45 \mathrm{~m}$ depth, whereas S2 was located at around $60 \mathrm{~m}$ depth (Fig. 1). The two sites were separated by a distance of $c a .5 \mathrm{~km}$ and they were composed of muddy sediments (99\% mud): S1 was characterized by $45 \%$ clay and $55 \%$ silt and $\mathrm{S} 2$ was composed of $64 \%$ clay and $36 \%$ silt (S1: $4.61 \pm 0.1$ and $\mathrm{S} 2: 2.71 \pm 0.05 \mu \mathrm{m}, \mathrm{D}_{50}$ median grain size). The $\mathrm{S} 1$ site receives the impact of the trawling fleet operating in the area and the S2 site is located around an abandoned 


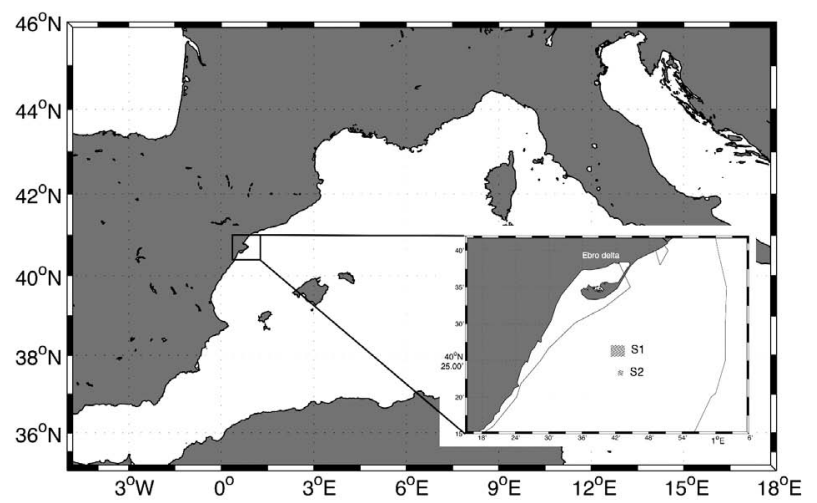

FIG. 1. - Study area located by the Ebro Delta in the northwestern Mediterranean. Detailed map including sites S1 and S2 and the 30 $\mathrm{m}$ and $80 \mathrm{~m}$ isoba

oil platform that trawlers avoid for their fishing operations. Its remains are small structures scattered over the seafloor that do not modify the physical conditions of the area (detailed description of the area in Demestre et al., 2008).

\section{Data collection}

Six sampling cruises were conducted from June to November 2003. Four cruises were undertaken in sum-

Organic matter

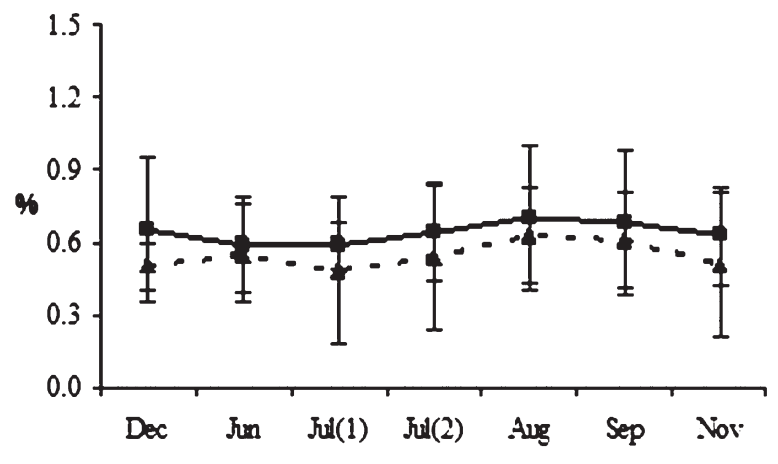

Bottom turtidity

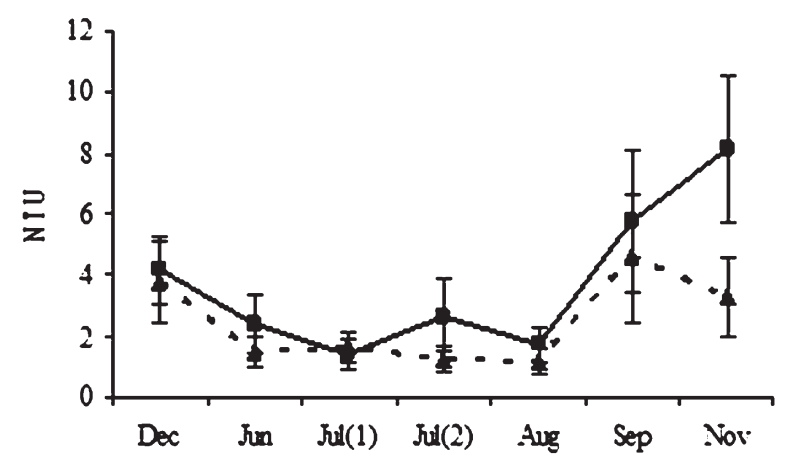

mer, on 27-30 June, 14-17 July, 28-31 July and 19-22 August; and two cruises took place in autumn, on 2629 September and 14-17 November. Sampling covered different environmental conditions in the Mediterranean, from warm water temperatures in summer months, with a marked thermocline, to lower temperatures in autumn characterized by the mix of the water column (Salat et al., 2002).

Samples were collected with a $0.1-\mathrm{m}^{2}$ van Veen grab at 5 sampling stations randomly located at the S1 and S2 sites, with 5 grabs collected at each station to obtain the minimum sample size (established after the accumulative abundance curves). Therefore, a total of 25 grabs were collected per site and cruise. Sediments were filtered over a $0.5-\mathrm{mm}$ sieve and the retained fraction was fixed in buffered formalin and dyed with Rose of Bengal to sort the organisms. The crustaceans were identified to species level and counted and weighed to subsequently analyse the species composition and community structural parameters (i.e. number of individuals, biomass as wet weight and the diversity indices species richness, Shannon diversity and Pielou's evenness).

Grain size and organic matter content were obtained from the sediment samples from one grab per sampling station. Additionally, a CTD transect of nine samples

Cay
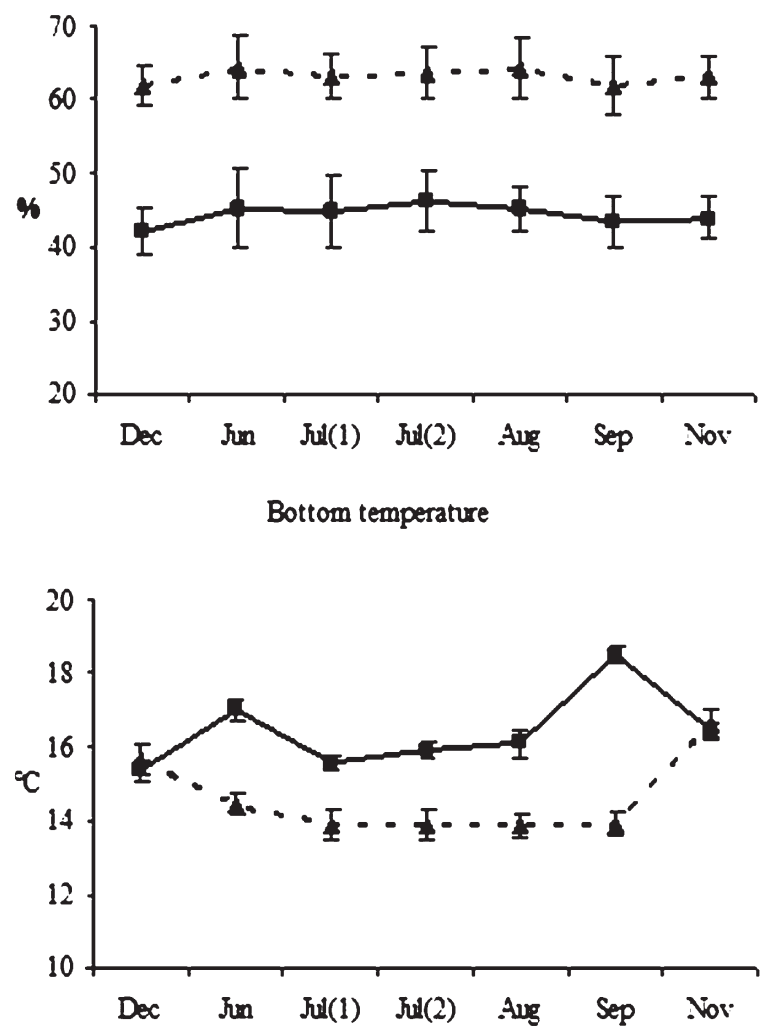

FIG. 2. - Temporal variability of the environmental variables: organic matter, $\%$ Clay and near-bottom turbidity and temperature (mean \pm SD). Data were recorded at S1 (black line) and S2 (dotted line) from December 2002 to November 2003, including June samples, Jun; first cruise of July, Jul(1); second cruise of July, Jul(2); August, Aug; September, Sep; and November, Nov. This figure was published in Cartes et al., 2009. 
covering S1 and S2 was done on each cruise to record surface and near-bottom temperature, and near-bottom turbidity. A suprabenthic sledge that was deployed to sample suprabenthos collected high concentrations of a mucilaginous aggregate (MA) at the end of July and August. This component, probably phytoplankton exudates, completely covered the seabed (as observed with the video records captured with a remotely operated vehicle). This variable was included as presence/ absence in the analysis as an important environmental factor potentially affecting the crustacean community.

The environmental variables surface and near-bottom temperature, near-bottom turbidity, mud, silt and clay percentages, organic matter content and the MA (Fig. 2) were correlated with the crustacean abundance data to estimate the influence of environmental variables in the distribution of crustacean species. A detailed explanation of the environmental data processing is included in Cartes et al. (2009) and Demestre (2006).

\section{Data analysis}

Differences between S1 and S2 over the six sampling cruises were tested with a two-way ANOVA (statistical package S-plus, Becker et al., 1988). The factors site and sampling month were considered as fixed factors. The interaction of the two factors indicates different be- haviour of the variables at each site over the sampling months. When normality assumptions were not met a $\log 10$ transformation was applied, and a KruskalWallis non-parametric test was performed if normality was not achieved. Multivariate analysis tested changes in the relative abundance of crustacean species across sites and experimental cruises. Analyses were done with PRIMER statistical package v.6 (Clarke and Warwick, 1994) and a square root transformation was applied to the data to downweight the dominant species. A SIMPER test was done to determine the species most characteristic at each site and the species responsible for the dissimilarities that might be detected between sites (through the Diss/SD index, the ratio of the average contribution to dissimilarity divided by the standard deviation of the contributions across pairs of samples). Non-metric multidimensional scaling (MDS) was done to obtain a graphical ordination of the samples based on the Bray-Curtis similarity (considering 50\%, 60\% and $80 \%$ similarity as thresholds), and the ANOSIM test was done to determine the significance of dissimilarities found between samples. To further analyze the factors that might determine the spatial and/or temporal ordination of samples, a principal coordinates analysis (PCO) based on the resemblance matrix was done with species data (after Bray-Curtis similarity) and environmental data (after Euclidean distance).

TABLE 1. - Crustacean species collected at S1 and S2. Mean abundance from samples collected from June to November (number of individuals $\mathrm{m}^{-2}$ )

\begin{tabular}{|c|c|c|c|c|c|}
\hline Crustacean species & S1 & S2 & Crustacean species & S1 & $\mathrm{S} 2$ \\
\hline Decapoda & & & Amphipoda & & \\
\hline F. Alpheidae & $<1$ & $<1$ & F. Ampeliscidae & $<1$ & $<1$ \\
\hline Alpheus glaber & 2 & 1 & F. Lysianassidae & $<1$ & 2 \\
\hline A. macrocheles & $<1$ & $<1$ & F. Oedicerotidae & $<1$ & 0 \\
\hline Callianassa tyrrhena & 2 & 3 & Acidostoma sarsi & $<1$ & 0 \\
\hline Corystes cassivelaunus & 0 & 1 & Ampelisca gibba & $<1$ & 1 \\
\hline Ebalia sp. & $<1$ & $<1$ & A. tenuicornis & 38 & 108 \\
\hline Galathea sp. & 0 & $<1$ & Aristias neglectus & $<1$ & 1 \\
\hline Goneplax rhomboides & 2 & 2 & Corophium rotundirostre & 40 & 70 \\
\hline Jaxea nocturna & 1 & $<1$ & Cheirocratus sp. & 1 & 1 \\
\hline Processa nouveli & 3 & 3 & Eusirus longipes & 0 & $<1$ \\
\hline Upogebia megalopa & $<1$ & 0 & Gammaropsis sp. & $<1$ & 1 \\
\hline U. typica & $<1$ & $<1$ & Harpinia crenulata & 6 & 5 \\
\hline Tanaidacea & 0 & $<1$ & H. dellavallei & 16 & 10 \\
\hline F. Tanaiidomorpha & 0 & $<1$ & Harpinia sp. & 87 & 106 \\
\hline Apseudes spinosus & 70 & 28 & H. truncata & $<1$ & 1 \\
\hline A. latreilli & 32 & 11 & Hippomedon bidentatus & 0 & $<1$ \\
\hline Cumacea & & & H. massiliensis & 0 & 2 \\
\hline Bodotria scorpioides & $<1$ & $<1$ & Jassa marmorata & $<1$ & $<1$ \\
\hline Diastylis doriphora & $<1$ & 2 & Lembos sp. & $<1$ & $<1$ \\
\hline D. rugosa & 1 & 2 & Leptocheirus sp. & 7 & 7 \\
\hline Diastyloides serrata & $<1$ & $<1$ & Leucothoe lilljeborgi & 6 & 3 \\
\hline Eudorella sp. & 3 & 4 & Maera schmidtii & 4 & 4 \\
\hline Iphinoe serrata & 4 & 3 & M. sodalis & 2 & 1 \\
\hline Leucon mediterraneus & 123 & 83 & Metaphoxus simplex & 5 & 115 \\
\hline Leucon sp. & $<1$ & 2 & Paracentromedon crenulatum & $<1$ & 0 \\
\hline Isopoda & & & Paraphoxus oculatus & 6 & 7 \\
\hline F. Arcturidae & 0 & $<1$ & Phtisica marina & 0 & $<1$ \\
\hline F. Bopyridae & $<1$ & 0 & Synchelidium maculatum & $<1$ & $<1$ \\
\hline Chelator chelatus & $<1$ & 2 & Tryphosella minima & $<1$ & $<1$ \\
\hline Desmosoma lineare & 0 & $<1$ & Tryphosites longipes & 0 & $<1$ \\
\hline Eugerda sp. & $<1$ & 1 & Westwodilla rectirostris & 1 & 1 \\
\hline \multirow[t]{3}{*}{ Gnathia sp. } & 1 & 9 & Mysidacea & $<1$ & $<1$ \\
\hline & & & Gastrosaccus normani & 2 & $<1$ \\
\hline & & & Siriella norvegica & $<1$ & 0 \\
\hline
\end{tabular}



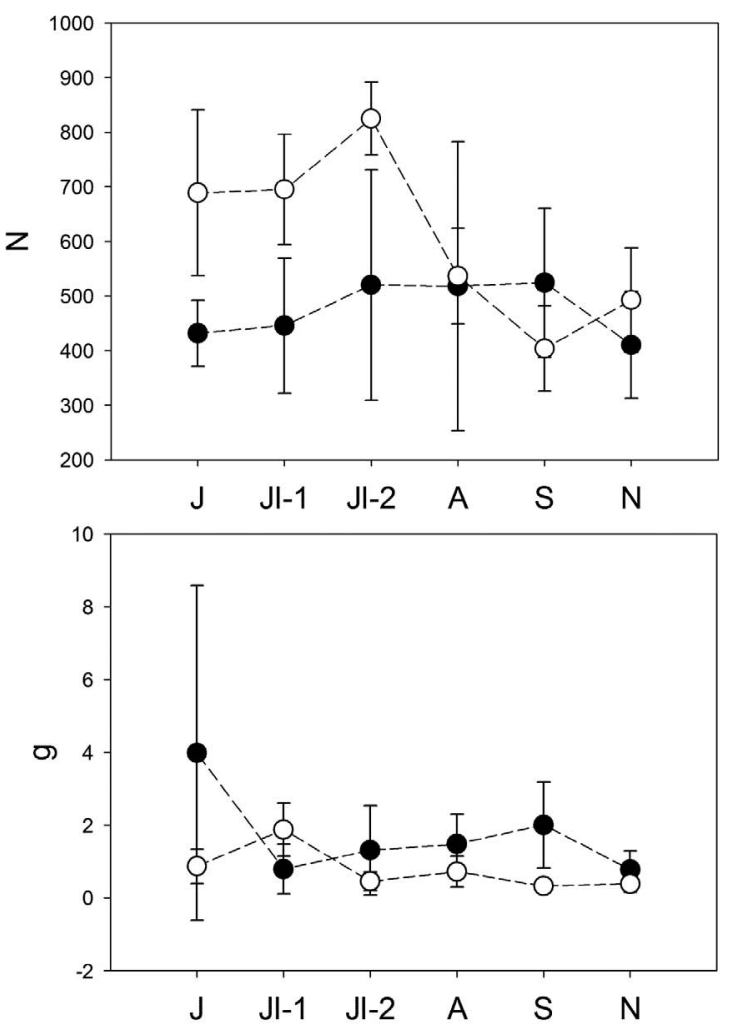

FIG. 3. - Mean abundance $\left(\mathrm{N} \mathrm{m}^{-2}\right)$ and mean biomass (wet weight $\mathrm{m}^{-2}$ ) collected at S1 (black circles) and S2 (open circles) from June to November 2003 (J, June; Jl-1, first cruise of July; J1-2, second cruise of July; A, August; S, September; N, November). Error bars are the standard deviation.

\section{RESULTS}

\section{Community structure}

A total of 64 species of crustaceans were collected (including individuals identified to family or higher taxonomical level), pertaining to the taxonomic orders Amphipoda, Cumacea, Decapoda, Isopoda, Mysidacea, and Tanaidacea (Table 1). Crustacean abundance at both sampling sites ranged between 404 and 824 individuals $\mathrm{m}^{-2}$. The temporal variability of abundance followed a different pattern at the two sites (Fig. 3a), with a peak of abundance occurring at S2 at the end of July and a subsequent decrease from August to September, while the abundance at $\mathrm{S} 1$ remained low $(P($ site $)<0.01 ; P($ site: month $)<0.01)$. The total crustacean biomass (Fig. 3b) was relatively low, with no significant differences between sites $\left(\mathrm{p}\left(\chi^{2}\right)=0.2\right)$. Species richness (Fig. 4a) showed a temporal pattern similar to abundance, with significant differences between sites $(P=0.01)$ and between months $(P=0.002)$. Shannon index $\left(\mathrm{H}^{\prime}\right)$ (Fig. 4b) and evenness (Fig. 4c) were similar at the two sites $(P($ site $)>0.05)$.

\section{Seasonal dynamics of crustacean species}

A subset of 22 species accounted for $80 \%$ of total crustacean abundance (Table 2). The Bray-Curtis similarity
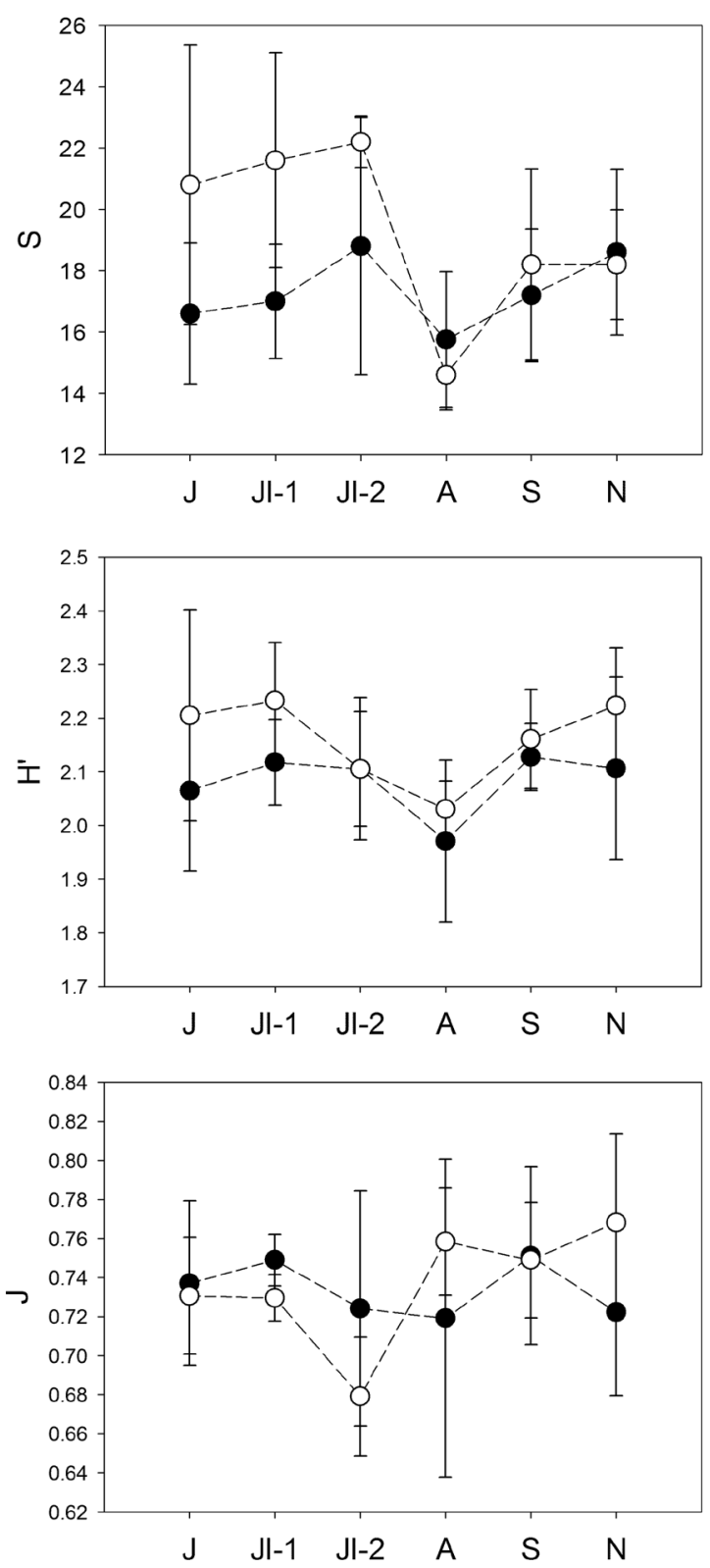

FIG. 4. - Mean ( $\pm \mathrm{SD}$ ) species richness (a), Shannon diversity (H'ln) (b) and Pielu's evenness (c) at S1 (black circles) and S2 (open circles) from June to November 2003 (J, June; Jl-1, first cruise of July; Jl-2, second cruise of July; A, August; S, September; N, November).

index determined $40.8 \%$ of dissimilarity between the two sites. Only four species held a high Diss/SD index ( $\geq 1.5)$ : the Amphipoda Metaphoxus simplex and Ampelisca tenuicornis, the Cumacea Leucon mediterraneus and the Isopoda Gnathia sp. The MDS ordination (Fig. 5) defines two groups of samples with $60 \%$ of similarity: one group includes S1 samples and the other group includes S2 samples $(0.18$ of stress; ANOSIM R $=0.90, P<0.01)$. The cluster defined by $70 \%$ similarity differentiated samples by month (ANOSIM R=0.53, $P<0.01$ ). November samples were different from all other samples at $\mathrm{S} 1$, and 3 clusters were defined at $\mathrm{S} 2$ : one including samples from 
TABLE 2. - Summary of SIMPER results: list of the species that account for $80 \%$ of total abundance at S1 and S2, dissimilarity index (Diss/S) between sites and \% contribution to total crustacean abundance.

\begin{tabular}{lcc}
\hline Species & Diss/SD & \% Contribution \\
\hline Metaphoxus simplex & 3.98 & 14.13 \\
Ampelisca tenuicornis & 1.53 & 6.65 \\
Leucon mediterraneus & 1.51 & 5.18 \\
Harpinia sp. & 1.39 & 5.09 \\
Apseudes latreillei & 1.20 & 5.03 \\
Apseudes spinosus & 1.30 & 4.86 \\
Harpinia dellavallei & 1.22 & 4.52 \\
Gnathia sp. & 1.79 & 3.97 \\
Corophium rotundirostre & 1.15 & 3.83 \\
Leptocheirus sp. & 1.23 & 2.90 \\
Harpinia crenulata & 0.78 & 2.83 \\
Leucothoe lilljeborgi & 1.20 & 2.75 \\
Paraphoxus oculatus & 1.30 & 2.58 \\
Maera schmidtii & 1.12 & 2.44 \\
Iphinoe serrata & 1.26 & 2.26 \\
Eudorella sp. & 1.18 & 2.20 \\
Processa nouveli & 1.21 & 2.11 \\
Callianassa tyrrhena & 1.23 & 1.68 \\
Goneplax rhomboides & 1.16 & 1.63 \\
Maera sodalis & 1.01 & 1.55 \\
Chelator chelatus & 0.79 & 1.52 \\
Alpheus glaber & 1.06 & 1.46 \\
\hline
\end{tabular}

June and July, one including samples from August and September, and one including samples from November. The PCO ordination (Fig. 6a) followed the same pattern, with the first axis explaining $29.5 \%$ of variation and differentiating the two sites, and the second axis explaining $16.8 \%$ of variance and differentiating samples by month, the clustering of samples by month being more marked at $\mathrm{S} 2$. The species holding a Pearson correlation index with the distribution of samples through the PCO axes above 0.6 were included in the graph (Fig. 6a), with a total of 9 species having a high correlation: Apseudes spinosus characterized S1; Harpinia dellavallei and Harpinia crenulata characterized S1 in autumn; Iphinoe serrata and Harpinia sp. characterized summer samples, the latter being more abundant at $\mathrm{S} 2$; Corophium rotundirostre and Ampelisca tenuicornis characterized S2 in July; and M. simplex and Gnathia sp. characterized S2 in autumn samples.

We selected those taxa holding a Diss/SD index above 1.5 , as well as those species with a Pearson correlation

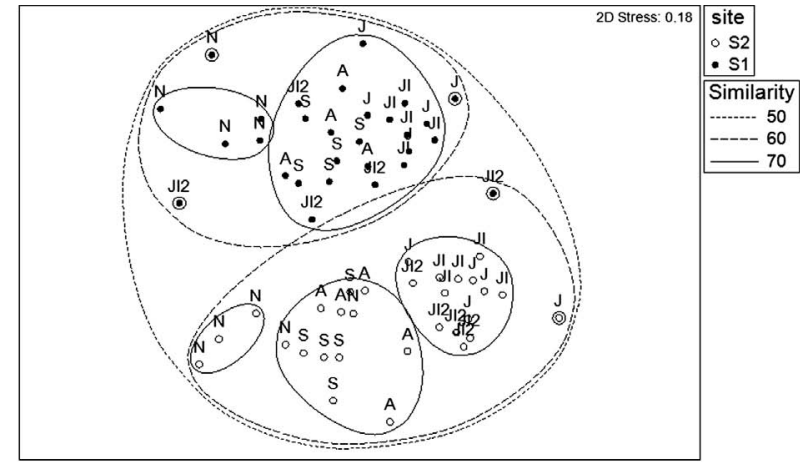

FIG. 5. - MDS plot based on crustacean species abundance at S1 and S2 (J, June; J1, first cruise of July; J12, second cruise of July; A, August; S, September; N, November). Lines define groups with $50 \%, 60 \%$ and $70 \%$ Bray-Curtis similarity.
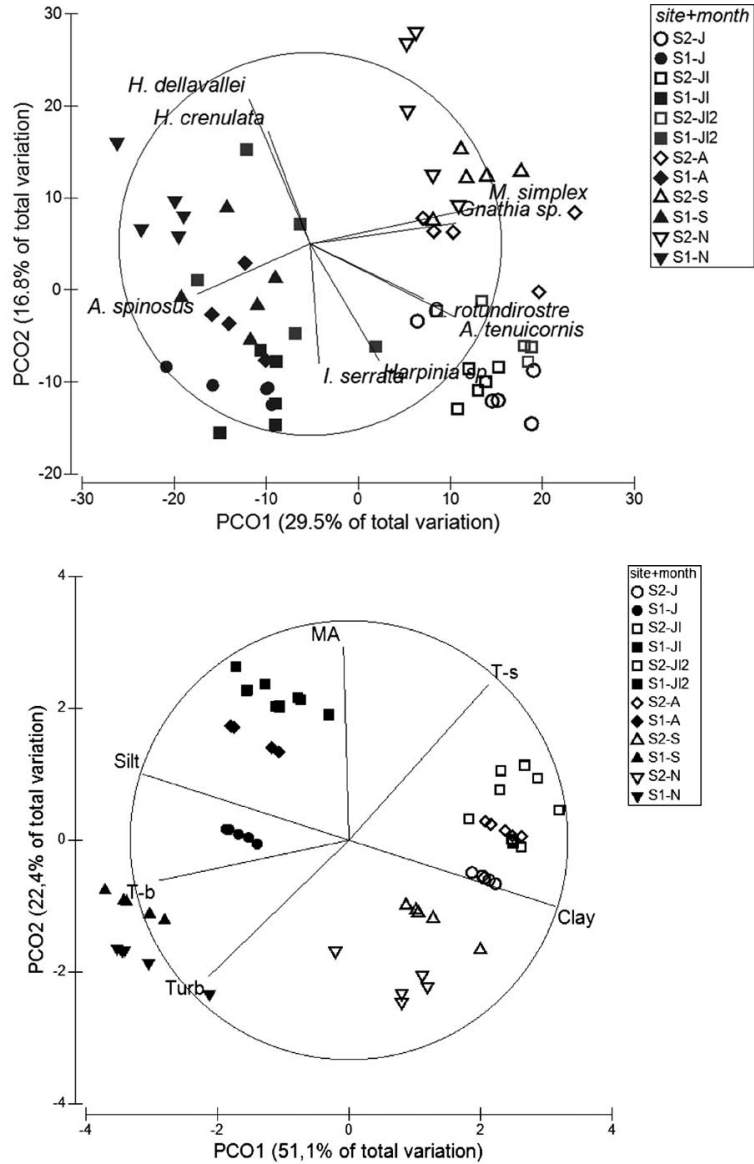

FIG. 6. - PCO plots based on the species abundance (a) and physical data (b) collected from June to November (J, June; Jl, first cruise of July; J12, second cruise of July; A, August; S, September; N, November). Vectors included for species/physical variables with Pearson correlation index $>0.6$. T- $b$ is the near-bottom temperature, $\mathrm{T}$-s is the difference between surface and bottom temperature, Turb is the near-bottom turbidity and MA is the mucilaginous aggregates. Black symbols S1 and open symbols S2.

index higher than 0.6. A total of 10 species resulted from this selection, including 6 Amphipoda (A. tenuicornis, $C$. rotundirostre, Harpinia sp., $H$. dellavallei, $H$. crenulata and $M$. simplex), 1 Tanaidacea (A. spinosus), 1 Isopoda (Gnathia sp.) and 2 Cumacea (I. serrata and L. mediterraneus). Changes in their abundance over space and time were as follows (Fig. 7): A. spinosus was significantly more abundant at $\mathrm{S} 1(P($ site $)<0.01)$, with no significant differences over time. The Amphipoda A. tenuicornis was significantly more abundant at $\mathrm{S} 2$ in summer months $(P$ (site:month $<0.01)$, whereas abundance at $\mathrm{S} 1$ remained invariable. The Amphipoda $C$. rotundirostre was generally more abundant at S2 $(P($ site:month $)<0.01)$. The Amphipoda Harpinia sp. and L. mediterraneus showed high variability but were characterized by a peak of abundance at $\mathrm{S} 2$ on the second cruise in July $(P($ site:month $)<0.01)$. The Isopoda Gnathia sp. and the Amphipoda M. simplex were almost absent from S1 and thus characterized S2. The Amphipoda $H$. crenulata and $H$. dellavalle $i$ and the Cumacea I. serrata, having similar abundance at the two sites, were collected in very low abundance. 

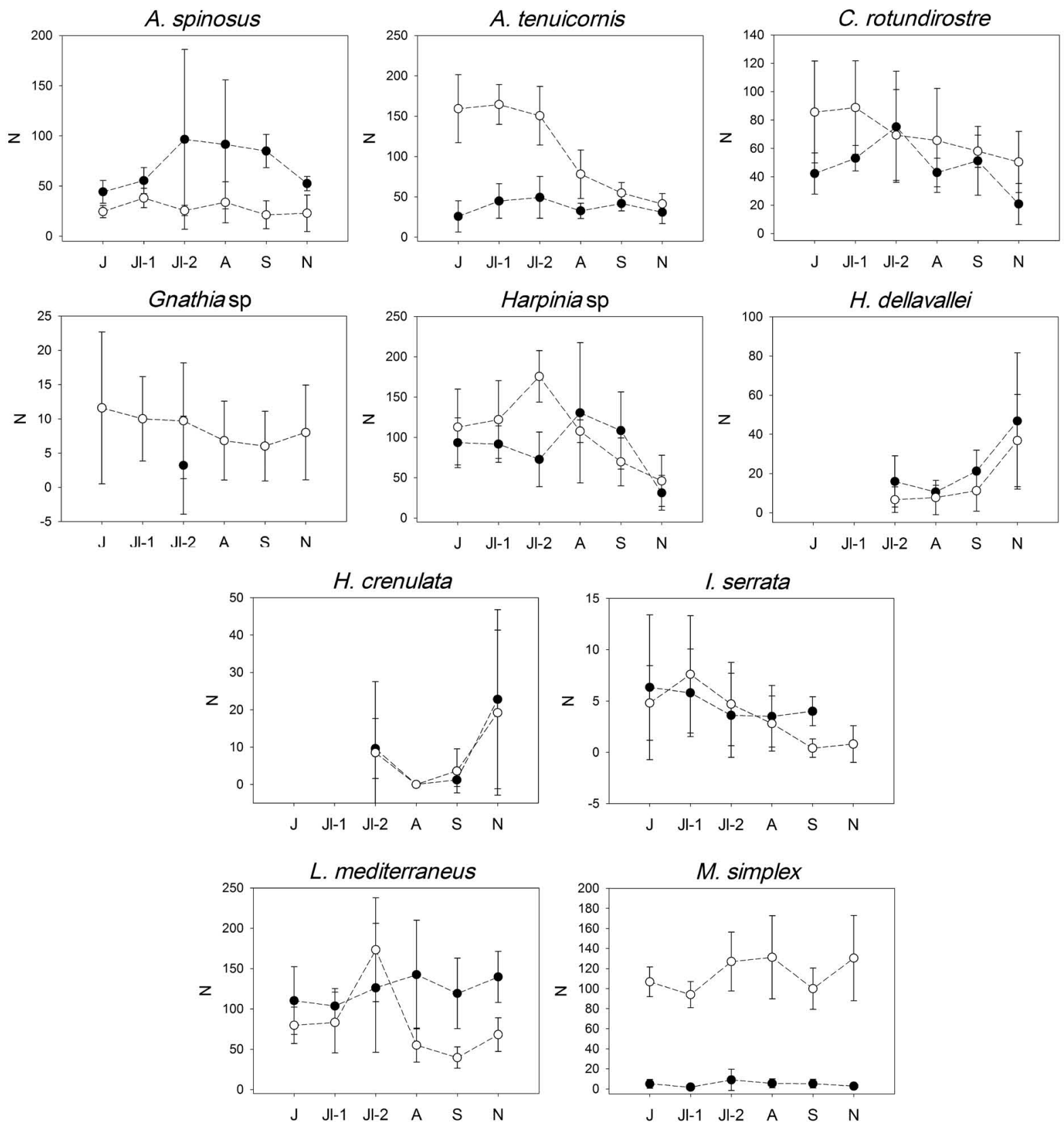

FIG. 7. - Mean $( \pm \mathrm{SD})$ abundance $\left(\mathrm{N} \mathrm{m}^{-2}\right)$ of crustacean species at $\mathrm{S} 1$ (black circles) and $\mathrm{S} 2$ (open circles).

\section{Influence of environmental data on crustacean abundance}

The PCO based on the environmental matrix (Fig. 6b) explained $73.5 \%$ of variance and was highly similar to the ordination based on the biological data. The first axis explained $51.1 \%$ of variation and differentiated the two sites, with \% clay characterizing S2 and \% silt characterizing $\mathrm{S} 1$. The second axis explained $22.4 \%$ of variance and differentiated autumn and summer samples; near-bottom turbidity and bottom temperature differentiated autumn samples at S1; and the difference between surface and bottom temperature differentiated summer samples mostly at S2. The MA characterized samples collected in summer months at both sites (see temporal pattern of physical variables in Fig. 2).

\section{DISCUSSION}

The infaunal crustacean community in the study area had relatively high species richness and abundance, with a total of 64 crustacean species, up to 800 individuals per $\mathrm{m}^{2}$, and a total of 151 taxa regarding all the infaunal assemblage (Ellingsen, 2001; De Biasi, 2004; de Juan et al., 2007a). A rich macroinfaunal community might be supported by the high river runoff 
at the Ebro Delta that may enhance phytoplankton production and originate the accumulation of fresh organic matter over the continental shelf (Hermand et al., 2008; Zajac, 2008). The accumulation of organic matter in a deltaic system can be directly exploited by suspension and deposit feeders enhancing the food web (Hermand et al., 2008). In the same area Cartes et al. (2007) observed changes in the suprabenthic community related to the environmental variability, and principally the hydrographic characteristics. The abundance of suprabenthos had two peaks, one in early summer and one in autumn, and a significant reduction in abundance in August. This pattern was similarly observed at S1 and S2, although S2 experienced a one-month delay. Previous studies have observed a tight relationship between the infaunal abundance and species richness and the sediment grain size (Ellingsen, 2002) and the organic content (Darnaude et al., 2004). In accordance with these studies, we expected the variability of infaunal crustaceans to be more related to the sediment characteristics and the organic matter content, less affected by the hydrographic variability, and potentially disturbed by fishing in S1. Peracarid crustaceans were dominant in our study community. As discussed by Cartes et al (2009), the particular development of peracarid crustaceans (embryos directly developed in marsupial bags of females) suggests low colonization abilities in comparison with planktotrophic taxa (e.g. polychaetes). Dominant species in the study community were tube dwellers and filter feeders (needing good sediment structure). All these features suggest that peracarids can be especially sensitive to environmental changes, both natural and human-induced, so they are a good target for studies regarding the short-term influence of environmental variability.

With few exceptions, the same species were collected at both sites despite some differences in depth $(45 \mathrm{~m}$ vs $60 \mathrm{~m})$. However, the multivariate analysis detected spatial differences based on the species relative abundance, with several species being more abundant at either site (i.e. Metaphoxus simplex, Ampelisca tenuicornis, Paraphoxus oculatus, Harpinia spp. and Gnathia spp. more abundant at S2, and Leucon mediterraneus, Apseudes spp., Iphinoe serrata and Harpinia dellavallei more abundant at $\mathrm{S} 1$ ). This ordination coincides with the ordination obtained with the physical variables: grain size-separated sites, with higher clay content at S2 and higher silt content at S1. Comparing these data with findings from other studies (e.g. Thrush et al., 2003; Chapman and Tolhurst, 2004), differences in mud content between locations might be too small to be affecting the faunal distribution (mud content is around $99 \%$ in both areas, varying the percentage of clay/silt). These slight differences in mud content could be related to the fact that the stations are near/ far from the river, as finer grain size occurs near the river because of sedimentation from terrestrial origin (Palanques et al., 2002). The effects of the river plume over the continental shelf are also related to higher or- ganic matter input on the seabed (Morris et al., 1995) and Cartes et al. (2009) found significant trends in the productivity of these species, with higher $\mathrm{P} / \mathrm{B}$ ratios at S1 attributable to higher food supply (OM content) and $\mathrm{C} / \mathrm{N}$ (organic matter quality). Similarly, a study carried out in front of the Rhone River (Darnaude et al., 2004; Hermand et al., 2008) detected OM of terrestrial origin at $100 \mathrm{~m}$ depth, with the macrobenthos enhancing benthic secondary production. Salat et al. (2002) found a major thermocline in the area of study between 50 and $60 \mathrm{~m}$, similar to that found in our study in summer (Cartes et al., 2009). We suggest that the river plume interacting with the thermocline induced gradients and changes in food quality at small spatial scales, the differences in the grain size being a surrogate for differences between S1 and S2. Dominant crustacean species on the Ebro Delta shelf are filter feeders (e.g. Ampelisca tenuicornis and Corophium sp.) or deposit feeders (e.g. Leucon mediterraneus) and they probably benefit from the arrival of fresh OM associated with river discharges. In this context, the local conditions for the productivity could explain the species segregation between $\mathrm{S} 1$ and $\mathrm{S} 2$.

The temporal dynamics of the infaunal crustaceans matched the seasonal pattern described in the area: increased river runoff and phytoplankton blooms in spring that supply organic matter to the seabed; the establishment of a thermocline with the high water temperature in summer, causing the shortage of organic matter supply to the seabed and possibly causing anoxic conditions at the end of summer; and in autumn a renewal of the bentho-pelagic fluxes because of the increase in turbidity and decrease in water temperature caused by autumn storms (Ambrogi et al., 1990; Sardá et al., 1999; Salat et al., 2002). The PCO ordination reflects this pattern, with summer samples characterized by the difference between surface and bottom temperature and autumn samples characterized by near-bottom turbidity and temperature. Moreover, our results showed that the total abundance and species richness at S2 was higher in June and July and significantly lower in August and through the autumn months. This peak of abundance could be related to a recruitment event because, remarkably, it was not parallel to an increase in biomass and diversity. Recruitment of peracarids has been described as coupled with inputs of fresh $\mathrm{OM}$ derived from surface production (Richoux et al., 2004). The same coupling was deduced for suprabenthos over the continental slope (Cartes et al., 2008).

Unfortunately, data on fresh OM were not available in our study (only data of total OM), which could explain the lack of correlation between OM and crustacean abundance. The depletion of crustacean abundance in August was also observed for the entire macroinfaunal community at S2 (unpublished data) and could therefore be related to the accumulation of mucilaginous aggregates (MA) observed in the study area in late July and August (Cartes et al., 2007). The high concentration of MA may be a consequence of 
the establishment of the thermocline and high water temperatures in summer (Sartoni et al., 2008). The experimental cruises were conducted in 2003, which was an exceptionally warm year. This could have increased the phytoplankton community abundance, which produced exudates (MA) (Underwood et al., 1995) that would sink and cover the seabed (as observed with the ROV, unpublished data), indirectly causing anoxia and reductions in faunal abundance. The MA significantly modifies the sediment properties, and studies suggest that it impoverishes the quality of available OM (Manini et al., 2000). In accordance with this, Cartes et al., 2007 observed an impoverishment of the quality of the OM that was probably related to the MA. Those species found among the most abundant in spring and early summer and with lesser abundance in late summer are the amphipods Ampelisca tenuicornis, Corophium rotundirostre and Harpinia sp. and the cumaceans Iphinoe serrata and Leucon mediterraneus, some of them suspension feeders (de Juan et al., 2007a), which would be highly affected by the accumulation of mucilage over the seabed. The MA disappeared in autumn months, characterized by the increase in near-bottom turbidity that indicates natural conditions of increasing storms and river discharge (data included in Cartes et al. 2007). This phenomenon would increase production and favour a second peak in abundance, observed in the suprabenthos but not in the infauna, probably because of a delay in response because the OM needs to accumulate in the seabed to be exploited by the infauna.

The crustacean abundance at $\mathrm{S} 1$ remained invariable throughout the study period, though this site was closer to the river mouth. A plausible explanation would be that the lower abundance at this site might be less influenced by the depletion of OM in summer. An alternative explanation is that fishing with trawling gears at S1 reduces the faunal abundance and disguises the effects of natural variability (Hall, 1999). The suprabenthic community followed a similar seasonal pattern at S1 and S2 (Cartes et al., 2007) and these swimming suprabenthic species can be expected to be less vulnerable to trawling than the sedentary infaunal crustaceans. The organisms that were collected at higher abundances at S1 (e.g. L. mediterraneus, Apseudes spp., I. serrata and H. dellavallei) can be considered as having lower vulnerability to trawling because, for instance, Apseudes spp. is a burrowing species and L. mediterraneus has a relatively high motility (de Juan et al., 2007a). The infaunal crustaceans hold a diversity of biological traits that will adapt either to natural or anthropogenic variability in the environment. Moreover, a fraction of the total variability between samples was not explained by the two axes of the PCO. This suggests that other variables not included in the analysis, such as the quality of the OM, micro-scale habitat variability and species interaction, could help to explain the variability in the community structure. The macroinfaunal organisms play important roles in the trophic webs in soft-bottoms of continental shelves, reaching high production rates (Wildish et al., 1992).
For example, macroinfaunal soft-bottom communities can constitute one of the major habitat quality components as prey of demersal species (Hinz et al., 2005). As an example, a previous study in the area detected that the diet of the commercially exploited spotted flounder (Citharus linguatula) was mainly based on Mysidacea and Cumacea (de Juan et al., 2007b). The biological traits and functional roles exhibited by the macrofauna vary with the environmental variability and can be profoundly modified by anthropogenic activities (Bremner et al., 2006). In our study the crustacean abundance at S1 was lower, probably as a consequence of trawling disturbance, and the abundance at S2 followed a marked seasonal variability, being strongly reduced at the end of summer. Improving our knowledge of the dynamics of the macroinfaunal communities is necessary as these assemblages are important components of soft-bottoms ecosystems. The study of macroinfaunal assemblages of Mediterranean continental shelves, especially focusing on the main environmental and anthropogenic factors controlling production and diversity, has received little attention, and this study highlights the importance of carrying out further studies on these community assemblages.

\section{ACKNOWLEDGEMENTS}

We would like to thank all participants in the RESPONSE project, particularly M. Demestre as coordinator of this project and A. Palanques for supplying the physical data. We are very grateful to all the persons participating in the VEDA cruises, including the crew from RV Garcia del Cid, and those who helped in the sorting and identification of fauna.

\section{REFERENCES}

Ambrogi, R., D. Bedulli and G. Zurijni. - 1990. Spatial and Temporal Patterns in Structure of Macrobenthic Assemblages. A Three-Year Study in the Northern Adriatic Sea in Front of the Po River Delta. Mar. Ecol., 11 (1): 25-41

Becker, R., J. Chambers and J. Wilks. - 1988. The new S language. A programming environment for data analysis and graphics. Wadsworth and Brooks, Pacific Grove, CA: Cole Advanced Books and Software.

Bremner, J., S. Rogers and C. Frid. - 2006. Matching biological traits to environmental conditions in marine benthic ecosystems. J. Mar. Sys., 60 (3-4): 302-316.

Buchanan, J. and R.M. Warwick. - 1974. An estimate of benthic macrofaunal production in the offshore mud of the Northumberland coast. J. Mar. Biol. Assoc. U.K., 54: 197-222.

Buhl-Jensen, L. and J. Fosså. - 1991. Hyperbenthic crustacean fauna of the Gullmarfjord area (western Sweden): Species richness, seasonal variation and long-term changes. Mar. Biol., 109(1): 245-258.

Cartes, J., V. Papiol, A. Palanques, J. Guillen and M. Demestre. 2007. Dynamics of suprabenthos off the Ebro Delta (Catalan Sea: western Mediterranean): Spatial 13 and temporal patterns and relationships with environmental factors. Estuar. Coast. Shelf Sci., 75(4): 501-515.

Cartes, J.E., T. Madurell, E. Fanelli and J.L. López-Jurado. - 2008. Dynamics of suprabenthos-zooplankton communities around the Balearic Islands (NW Mediterranean): influence of environmental variables and effects on higher trophic levels. J. Mar. Sys., 71(3-4): 316-335.

Cartes, J.E., A. Ligas, A. De Biasi, L. Pacciardi and P. Sartor. - 
2009. Small-spatial scale changes in productivity of suprabenthic and infaunal crustaceans at the continental shelf of Ebro Delta (western Mediterranean). J. Exp. Mar. Biol. Ecol., 378(12): 40-49.

Chapman, M.G. and T.J. Tolhurst. - 2004. The relationship between invertebrate assemblages and bio-dependant properties of sediment in urbanized temperate mangrove forests. J. Exp. Mar. Biol. Ecol., 304(1): 51-73.

Clarke, K.R. and M. Ainsworth. - 1993. A method of linking multivariate community structure to environmental variables. Mar. Ecol. Prog. Ser., 92(3): 205-219.

Clarke, K.R. and R.M. Warwick. - 1994. Changes in marine communities: an approach to statistical analysis and interpretation, Plymouth: Natural Environment Research Council, UK.

Darnaude, A.M., C. Salen-Picard, M.L. Harmelin-Vivien. - 2004. Depth variation in terrestrial particulate organic matter exploitation by marine coastal benthic communities off the Rhone River delta (NW Mediterranean). Mar. Ecol. Prog. Ser., 275: 47-57.

Dauvin, J. and F. Gentil. - 1990. Conditions of the Peracarid populations of subtidal communities in Northern Brittany ten years after the Amoco Cadiz oil spill. Mar. Pollut. Bull., 21(3): 123-130.

De Biasi, A. - 2004. Impact of experimental trawling on the benthic assemblage along the Tuscany coast (north Tyrrhenian Sea, Italy). ICES J. Mar. Sci., 61(8): 1260-1266.

de Juan, S., S. Thrush and M. Demestre. - 2007a. Functional changes as indicators of trawling disturbance on a benthic community located in a fishing ground (NW Mediterranean Sea). Mar. Ecol. Prog. Ser., 334: 117-129.

de Juan, S., J.E. Cartes, M. Demestre. - 2007b. Effects of commercial trawling activities in the diet of the flat fish Citharus linguatula (Osteichthyes: Pleuronectiformes) and the starfish Astropecten irregularis (Echinodermata: Asteroidea). J. Exp. Mar. Biol. Ecol., 349: 152-169.

Demestre, M. - 2006. Response of benthic communities and sediment to different regimens of fishing disturbance in European coastal waters (Q5RS-2002-00787, E U Projects). ICM-CSIC, Barcelona, Spain.

Demestre, M., S. de Juan, P. Sartor and A. Ligas. - 2008. Seasonal closures as a measure of trawling effort control in two Mediterranean trawling grounds: Effects on epibenthic communities. Mar. Pollut. Bull., 56: 1765-1773.

Drinkwater, K. and K. Frank. - 1994. Effects of river regulation and diversion on marine fish and invertebrates. Aquat. Conserv., 4(2): 135-151.

Ellingsen, K.E. - 2001. Biodiversity of a continental shelf softsediment macrobenthos community. Mar. Ecol. Prog. Ser., 218: $1-15$.

Ellingsen, K.E. - 2002. Soft-sediment benthic biodiversity on the continental shelf in relation to environmental variability. Mar. Ecol. Prog. Ser., 232: 15-27.

Ellingsen, K.E. and J.S. Gray. - 2002. Spatial patterns of benthic diversity: is there a latitudinal gradient along the Norwegian continental shelf? J. Anim. Ecol., 71: 373-389.

Gobin, J. and R.M. Warwick. - 2006. Geographical variation in species diversity: A comparison of marine polychaetes and nematodes. J. Exp. Mar. Biol. Ecol., 330(1): 234-244.

Gray, J.S. - 2000. The measurement of marine species diversity, with an application to the benthic fauna of the Norwegian continental shelf. J. Exp. Mar. Biol. Ecol., 250(1-2): 23-49.

Gremare, A., J.M. Amoroux, F. Charles, A. Dinet, C. Riaux-Gobin, J. Baudart, L. Medernach, J.Y. Bodiou, G. Vetion, J.C. Colomines, A. Albert. - 1997. Temporal changes in the biochemical composition and nutritional value of the particulate organic matter available to surface deposit-feeders: a two year study. Mar. Ecol. Prog. Ser., 150(1): 195-206.

Gremare, A., J.M. Amouroux and G. Vetion. - 1998. Long-term comparison of macrobenthos within the soft bottoms of the Bay of Banyuls-sur-mer (northwestern Mediterranean Sea). J. Sea Res., 40: 281-302.

Hall, S. - 1999. The effects of fishing on marine ecosystems and communities. Blackwell, Oxford.

Hermand, R., C. Salen-Picard, G. Alliot and C. Degiovanni. - 2008. Macrofaunal density, biomass and composition of estuarine sediments and their relationship to the river plume of the Rhone River (NW Mediterranean). Estuar. Coast. Shelf Sci., 79(3): 367-376.
Hewitt, J.E, S.F. Thrush, J. Halliday and C. Duffy. - 2005. The importance of small-scale habitat structure for maintaining beta diversity. Ecology, 86(6): 1619-1626.

Hinz, H., I. Kroncke and S. Ehrich. - 2005. The feeding strategy of dab Limanda limanda in the southern North Sea: linking stomachs contents to prey availability in the environment. J. Fish Biol., 67: 125-145.

Lohrer, A.M., S.F. Thrush and M. Gibbs. - 2004. Bioturbators enhance ecosystem function through complex biogeochemical interactions. Nature, 431: 1092-1095.

Manini, E., M. Fabiano and R. Danovaro. - 2000. Benthic response to mucilaginous aggregates in the northern Adriatic Sea: Biochemical indicators of eutrophication. Chem. Ecol., 17(3): 71-179.

Morris, A.W., J.I. Allen, R.J.M. Howland and R.G. Wood. - 1995. The Estuary Plume Zone: source or sink for land-derived nutrient discharges. Estuar. Coast. Shelf Sci., 40: 387-402.

Oczkowski, A.J., S. W. Nixon, S.L. Granger, A.M. El-Sayed and R.A. McKinney. - 2009. Anthropogenic enhancement of Egypt's Mediterranean fishery. PNAS, 106(5): 10-13.

Palanques, A. and D. Drake. - 1990. Distribution and dispersal patterns of suspended particulate matter on the Ebro continental shelf, Northwestern Mediterranean. Mar. Geol., 95: 193-206.

Palanques, A., P. Puig, J. Guillen, J. Jimenez., V. Gracia, A. Sanchez-Arcilla and O. Madsen. - 2002. Near-bottom suspended sediment fluxes on the microtidal low-energy Ebro continental shelf (NW Mediterranean). Cont. Shelf Res., 22: 285-303.

Pearson, T. and R. Rosenberg. - 1978. Macrobenthic succession in relation to organic enrichment and pollution on the marine environment. Oceanogr. Mar. Biol. Annu. Rev., 16: 229-311.

Richoux, N.B., D. Deibel and R.J. Thompson. - 2004. Population biology of hyperbenthic crustaceans in a cold water environment (Conception Bay, Newfoundland). 1. Mysis mixta (Mysidacea). Mar. Biol., 144(5): 881-894.

Salat, J., M.A. Garcia, A. Cruzado, A. Palanques, L. Arin, D. Gomis, J. Guillen, A. de Leon, J. Puigdefabregas, J. Sospedra and Z.R. Velasquez. - 2002. Seasonal changes of water mass structure and shelf slope exchanges at the Ebro Shelf (NW Mediterranean). Cont. Shelf Res., 22(2): 327-348.

Salen-Picard, C., D. Arlhac and E. Alliot. - 2003. Responses of a Mediterranean soft bottom community to short-term (1993 -1996) hydrological changes in the Rhone River. Mar. Environ. Res., 55: 409-427.

Sardá, R., S. Pinedo and D. Martin. - 1999. Seasonal dynamics of macroinfaunal key species inhabiting shallow soft-bottoms in the Bay of Blanes (NW Mediterranean). Acta Oecol., 20(4): 315-326.

Sartoni, G., R. Urbani, P. Sist, D. Berto, C. Nuccio and M. Giani. -2008 . Benthic mucilaginous aggregates in the Mediterranean Sea: Origin, chemical composition and polysaccharide characterization. Mar. Chem., 111(3-4): 184-198.

Snelgrove, P.V. - 1998. The biodiversity of macrofaunal organisms in marine sediments. Biodivers. Conserv., 7: 1123-1132.

Thrush, S.F., J.E. Hewitt, A. Norkko, P.E. Nicholls, G.A. Funnell and J.I. Ellis. - 2003. Habitat change in estuaries: Predicting broad-scale responses of intertidal macrofauna to sediment mud content. Mar. Ecol. Prog. Ser., 263: 101-112.

Thrush, S.F., J.S. Gray, J.E. Hewitt and K.I. Ugland. - 2006. Predicting the effects of habitat homogenization on marine biodiversity. Ecol. Appl., 16(5): 1636-1642.

Underwood, G.J., D.M. Paterson and R.J. Parkes. - 1995. The measurement of microbial carbohydrate exopolymers from intertidal sediments. Limnol. Oceanogr., 40(7): 1243-1253.

Warwick, R.M. - 1982. The partitioning of secondary production among species in benthic communities. Netherlands J. Sea Res., 16: 1-16.

Wildish, D.J., A.J. Wilson and B. Frost. - 1992. Benthic boundary layer macrofauna of Browns Bank, Northwest Atlantic, as potential prey of juvenile benthic fish. C. J. Fish. Aquat. Sci., 49: 91-98.

Zajac, R.N. - 2008. Macrobenthic biodiversity and sea floor landscape structure. J. Exp. Mar. Biol. Ecol., 366(1-2): 198-203.

Scient. ed.: J.G. Hiddink.

Received December 3, 2010. Accepted March 14, 2011.

Published online August 22, 2011. 